\title{
PENGARUH MODEL PEMBELAJARAN QUANTUM TEACHING DENGAN TERAPAN METODE SCAFFOLDING TERHADAP PENINGKATAN KEMAMPUAN PEMECAHAN MASALAH MATEMATIS DAN MOTIVASI BELAJAR MATEMATIKA SISWA KELAS VII SMP
}

\author{
Nurlina Ariani Hrp ${ }^{1 *}$, Panggih Nur Adi ${ }^{2}$ \\ ${ }^{1,2}$ Prodi Pendidikan Matematika, Universitas Labuhanbatu \\ Jln. Sisingamangaraja No. 126A Km.3,5 Aek Tapa Rantauprapat, Sumatera Utara, Indonesia \\ e-mail: ${ }^{1}$ nurlinaariani561@ gmail.com; ${ }^{2}$ panggi.s3@gmail.com; \\ Submitted: September 02, 2021 \\ Revised: November 03, 2021 \\ Accepted: November 07, 2021 \\ corresponding author*
}

\begin{abstract}
Abstrak
Penelitian ini bertujuan untuk mengetahui pengaruh model pembelajaran Quantum Teaching dengan terapan metode scaffolding terhadap peningkatan kemampuan pemecahan masalah matematis dan motivasi belajar siswa di SMP Negeri 1 Torgamba Sumatera Utara. Penelitian dilakukan berdasarkan karena rendahnya kemampuan pemecahan masalah dan motivasi belajar matematika siswa pada siswa kelas VII di sekolah tersebut. Penelitian menggunakan model pembelajaran Quantum Teaching yang diterapkan dengan metode scaffolding. Model pembelajaran Quantum Teaching merupakan cara baru yang memudahkan proses belajar, yang memadukan unsur seni dan pencapaian terarah untuk segala mata pelajaran dengan menggabungkan keistimewaan-keistimewaan belajar menuju bentuk perencanaan pengajaran yang akan meningkatkan prestasi siswa. Metode penelitian ini menggunakan eksperimen jenis eksperimen semu dengan bentuk desain yang digunakan adalah One-Group Pretest-Posttest. Populasi dalam penelitian ini adalah siswa kelas VII dengan sampel 2 kelas sebagai kelas ekperimen dan kontrol dengan jumlah masing-masing 30 orang. Teknik pengumpulan data yang digunakan adalah metode tes dan angket kuisioner. Teknik analisis data yang digunakan adalah teknik statistik deskriptif dan inferensial. Teknik statistik deskriptif digunakan untuk mendeskripsikan data nilai rata-rata (mean), median, modus, standar deviasi dan kecenderungan data. Teknik statistik inferensial digunakan untuk menguji hipotesis penelitian, dimana teknik inferensial yang akan digunakan adalah teknik analisis varian dua jalur (disain faktorial 2x2) pada taraf signifikansi 5\%. Hasil pengujian statistik untuk data kemampuan pemecahan masalah pada kelas eksperimen dibandingkan kelas kontrol dengan menggunakan uji t sebagai uji hipotesis, yaitu hasil t hitung $>\mathrm{t}$ tabel dimana $\mathrm{t}$ hitung $=1,43$ dan $\mathrm{t}$ tabel $=1,03$ dengan taraf signifikansi 5\%. Sedangkan untuk data motivasi belajar pada taraf signifikansi $\alpha=0,05$ diperoleh $t_{\text {hitung }}$ sebesar 5,83 dengan nilai signifikansi 0,000 sedangkan $t_{\text {tabel }}$ sebesar 4,42. Karena $\mathrm{t}_{\text {hitung }}>\mathrm{t}_{\text {tabel }}(5,83>4,42)$ dan signifikansi $<0,05(0,000<0,05)$ sehingga disimpulkan bahwa terdapat pengaruh yang signifikan dari penggunaan model quantum teaching terapan metode scaffolding terhadap peningkatan kemampuan pemecahan masalah dan motivasi belajar matematika siswa.
\end{abstract}

Kata Kunci: motivasi, pemecahan masalah, scaffolding, quantum teaching

\section{THE EFFECT OF QUANTUM LEARNING MODEL APPLIED SCAFFOLDING METHOD ON INCREASES MATHEMATIC PROBLEM SOLVING ABILITY AND MOTIVATION TO STUDY MATHEMATICS FOR VII GRADE STUDENTS}

\begin{abstract}
This study aims to determine the effect of the Quantum Teaching learning model with the application of the scaffolding method on increasing mathematical problem solving abilities and student motivation at SMP Negeri 1 Torgamba, North Sumatra. Quantum teaching learning model is a new way that facilitates the learning process, which combines elements of art and targeted achievement for all subjects by combining learning features into a form of teaching planning that will improve student achievement. This research method uses a quasi-experimental type of experiment with the form of design used is One-Group Pretest-Posttest. The population in this study was class VII students with a sample of 2 classes as
\end{abstract}


experimental and control classes with a total of 30 people each. Data collection techniques used are test methods and questionnaires. The data analysis technique used is descriptive and inferential statistical techniques. Descriptive statistical techniques were used to describe the data of the mean (mean), median, mode, standard deviation and trend of the data. Inferential statistical technique is used to test the research hypothesis, where the inferential technique to be used is the two-way analysis of variance technique $(2 \times 2$ factorial design) at a significance level of 0.05 . The results of statistical testing in the experimental class were compared to the control class using the $t$ test as a hypothesis test, namely the results of $t$ count $>t$ table where $\mathrm{t}$ count $=1.43$ and $\mathrm{t}$ table $=1.03$ with a significance level of $5 \%$ so that $\mathrm{H} 1$ is accepted and H0 is rejected. It was concluded that there was a significant effect between increases students' mathematical problem solving abilities using the applied quantum teaching model of the scaffolding method and students' mathematical problem solving abilities using ordinary learning models

Keywords: motivation, problem solving, scaffolding, quantum teaching

\section{Pendahuluan}

Pendidikan merupakan pondasi utama dalam peningkatan kemajuan suatu bangsa dan negara. Negara yang maju adalah Negara yang memiliki program pelaksanaan pendidikan dengan merata dalam keseluruhan kawasan daerahnya. Berhasilnya suatu program pendidikan merupakan cerminan dari terlaksananya dengan baik sistem pendidikan oleh para pendidik dan tenaga kependidikan dimana pelaksanaan pendidikan tersebut mempunyai sistem yang terencana dan terlaksana dengan semua unsurnya.

Salah satu tujuan pembelajaran matematika adalah mampu meningkatkan kemampuan pemecahan masalah matematis. Kemampuan pemecahan masalah matematis sangat tergantung dengan masalah yang terdapat dalam matematika. Berdasarkan strukturnya, masalah dapat dibedakan dalam dua jenis, yaitu masalah terdefinisi dengan baik (well defined) dan masalah tidak didefenisikan dengan baik (ill defined). Sedangkan berdasarkan konteksnya masalah diidentifikasikan menjadi masalah matematis yang berkaitan dengan dunia nyata dan masalah matematis murni (pure mathematical problems) yang melekat secara keseluruhan dalam matematika (Prabawanto, 2013). Proses pemecahan masalah matematik berbeda dengan proses menyelesaikan soal matematika.

Menyelesaikan soal atau tugas matematik belum tentu sama dengan memecahkan masalah matematik (Hendriana, dkk, 2016). Dalam proses pembelajaran maupun dalam kehidupan seharihari, kemampuan pemecahan masalah ini sangat penting. Pemecahan masalah sebagai langkah awal siswa dalam mengembangkan ide-ide dalam membangun pengetahuan baru dan mengembangkan keterampilan keterampilan matematika (Rianto, dkk., 2016). Kemampuan pemecahan masalah adalah suatu keterampilan pada diri peserta didik agar mampu secara matematis memecahkan masalah yang berhubungan dengan matematika atau dalam ilmu lainnya dan masalah yang sering dijumpai siswa di kehidupan nyata (Tomo, dkk., 2016). Sebuah penelitian oleh Mulyati yang menyatakan bahwa kurangnya perhatian guru terhadap pengembangan kemampuan pemecahan masalah dalam proses pembelajaran matematika mengakibatkan siswa kurang memiliki kemampuan pemecahan masalah. Kekurangan masalah non-rutin dalam buku sumber (teks) menjadi salah satu penyebabnya, selain itu guru terbiasa mengadopsi soal-soal yang terdapat pada buku sumber pembelajaran. Pemberian soal nonrutin merupakan salah satu cara agar kemampuan pemecahan masalah siswa dapat berkembang.

Hal ini mengindikasikan bahwa dengan secara rutin memberikan soal dengan menerapkan indikator pemecahan masalah matematis maka akan melatih siswa untuk semakin mampu dan mahir dalam menyelesaikan masalah matematis secara baik. Adapun indikator kemampuan pemecahan masalah menurut Sumarmo (2012) sebagai berikut: mengidentifikasi unsur yang diketahui, ditanyakan, dan kecukupan unsur, (2) membuat model matematika, (3) menerapkan strategi menyelesaikan masalah dalam/ diluar matematika, (4) menjelaskan/ menginterpretasikan hasil, (5) menyelesaikan model matematika dan masalah nyata, (6) menggunakan matematika secara bermakna.

Keberhasilan pembelajaran dikelas dilihat dari seberapa besar siswa mengikuti pembelajaran dengan baik dari awal sampai akhir dengan semangat dan bersinergi. Hal ini tergantung seberapa besar motivasi siswa untuk mengikuti pembelajaran dikelas bersama teman dan guru sebagai pengajar. Motivasi adalah suatu perubahan energi di dalam diri pribadi seseorang yang ditandai dengan timbulnya afektif, dan reaksi untuk mencapai tujuan, juga sebagai dorongan dari dalam diri seseorang dan dorongan 
ini merupakan motor penggerak (Uno, 2010). Motivasi merupakan faktor penggerak atau dorongan seseorang untuk melakukan kegiatan tertentu yang dimaksudkan untuk mencapai tujuan. Sehingga motivasi menentukan tingkat aktivitas seseorang, semakin tinggi motivasi seseorang maka semakin besar pula aktivitas dan usaha yang dilakukan untuk mencapai tujuan (Widayanti, 2011). Sehingga motivasi belajar sangat diperlukan untuk mencapai tujuan pembelajaran.

Unsur-unsur yang mempengaruhi motivasi belajar menurut yaitu (a) cita-cita atau aspirasi siswa, (b) kemampuan siswa, (c) kondisi siswa, (d) kondisi lingkungan siswa, (e) unsur-unsur dinamis dalam belajar dan pembelajaran, dan (f) upaya guru dalam membelajarkan siswa (Dimyati, dkk., 2013). Sehingga motivasi belajar menurut peneliti merupakan dorongan baik dari dalam maupun dari luar pribadi seseorang untuk melakukan kegiatan dalam mencapai tujuan pembelajaran yaitu berusaha untuk merubah diri dari yang belum tahu menjadi tahu, dari yang belum paham menjadi paham, sehingga dapat mencapai tujuan pembelajaran dengan maksimal. Sebuah penelitian yang dilakukan oleh Hasanah, dalam penelitian beliau disebutkan bahwa penerapan model pembelajaran yang lain dari yang biasanya dapat meningkatkan motivasi belajar siswa, dari analisis kualitatif terlihat bahwa terjadi perbaikan proses pembelajaran serta peningkatan motivasi belajar matematika di dalam kelas dari sebelum ke setelah tindakan dengan $\mathrm{P}=0,001<\alpha=00,5$ (Hasanah, 2020). Oleh karena itu, motivasi sebagai proses batin atau proses psikologis yang terjadi pada diri seseorang sangat dipengaruhi oleh faktor eksternal (lingkungan), dan faktor internal yang melekat pada setiap orang (pembawaan), tingkat pendidikan, pengalaman masa lalu, keinginan atau harapan masa depan.

Hal-hal di atas sangat mendukung dalam penelitian di SMP Negeri 1 Torgamba, karena sesuai dengan adanya permasalahan yang terjadi di SMP negeri 1 Torgamba yaitu rendahnya motivasi belajar dan kemampuan pemecahan masalah matematis siswa dalam pembelajaran matematika. Guru memberikan keterangan bahwa siswa mengalami penurunan nilai untuk indikator menyelesaikan masalah dalam soal-soal matematika yang berbentuk soal berbasis masalah kemudian siswa juga mengalami penurunan motivasi belajar matematika disetiap jam pelajaran matematika. Hal ini juga didukung dengan adanya data observasi awal juga pemberian tes awal beserta angket motivasi belajar untuk membuktikan bahwa keteranganketerangan tersebut memang benar kemudian pantas untuk dilakukan penelitian untuk tujuan perbaikan peningkatan nilai hasil dan motivasi belajar siswa. Benar halnya, bahwa berdasarkan hasil penelusuran awal dan observasi data ditemukan permasalahan pada siswa SMP Negeri 1 Torgamba kelas VII tidak menyukai pembelajaran matematika. Peneliti mencari tahu sumber permasalahan terletak pada hal penggunaan model dan metode pembelajaran oleh guru matematika, yang akhirnya mengakibatkan motivasi belajar siswa sangat rendah sekali. Pencapaian indikator pemecahan masalah matematis siswa juga sangat rendah, hasil tes menunjukkan bahwa rendahnya nilai dalam rata-rata nilai adalah 40, dimana nilai ini tidak mencapai nilai KKM (Kriteria Ketuntasan Minimal) Matematika di sekolah tersebut yaitu 60 .

Rendahnya nilai kemampuan memecahkan masalah dalam matematika karena dengan alasan dalam pembelajaran guru hanya memberikan catatan rumus dan penggunaan rumus dalam soal saja agar siswa dapat menyelesaikan soal matematika dengan cepat tanpa menanamkan cara agar siswa memahami dan mampu menyelesaikan secara matematisnya yang bersifat pemecahan masalah. Selain itu, keterbatasan guru dalam penyampaian langkah-langkah penyelesaian masalah yaitu Memahami Masalah (Understanding) Merencanakan Penyelesaian (Planning) Menyelesaikan Masalah (Solving) Melakukan Pengecekan Kembali (Checking) dalam penyelesaian masalah matematis kegiatan kurang maksimal disebabkan tuntutan ketercapaian mengajar dikelas. Penyebab lain, ialah salahnya guru beranggapan bahwa siswa bekerja secara berkelompok membutuhkan waktu yang cukup lama dan sering terjadinya keributan di dalam pembelajaran, sehingga proses pembelajaran seperti itu akan mengganggu program pembelajaran yang sudah di buat sebelumnya. Data ini menjadi dasar kuat peneliti untuk melihat lebih dalam dan mencoba melakukan penelitian dalam upaya memberikan solusi untuk perbaikan yang bisa meningkatkan kemampuan pemecahan masalah dan motivasi belajar matematika siswa pada sekolah tersebut. Hal ini juga didasari dengan adanya program penelitian dosen oleh Kemendikbudristek Direktorat Jenderal Pendidikan Tinggi, Riset dan Teknologi, dengan program ini menjadi mempermudah peneliti untuk melakukan penelitian pada sekolah dengan masalah yang perlu dipecahkan. 
Berdasarkan beberapa penelitian sebelumnya oleh peneliti lain, bahwa permasalahan seperti ini dapat diatasi dengan menerapkan pembelajaran yang mengubah belajar menjadi lebih meriah, dengan nuansa yang memaksimalkan momen belajar dan fokus pada lingkungan kelas, yang melatih siswa meningkatkan kemampuan matematisnya. Perlunya model pembelajaran yang dapat menciptakan suasana belajar yang menyenangkan adalah dapat membuat proses berpikir siswa menjadi lebih optimal sehingga lebih mudah untuk mengembangkan seluruh potensi siswa (Hasibuan, 2019). Salah satu cara tersebut adalah dengan memilih model pembelajaran Quantum Teaching.

Model quantum teaching merupakan cara baru yang memudahkan proses belajar, yang memadukan unsur seni dan pencapaian terarah untuk segala mata pelajaran dengan menggabungkan keistimewaan-keistimewaan belajar menuju bentuk perencanaan pengajaran yang akan melejitkan prestasi siswa (Made, 2013). Model quantum teaching adalah pengubahan belajar yang meriah dengan segala nuansanya yang menyertakan segala kaitan, interaksi, dan perbedaan yang memaksimalkan momen belajar serta berfokus pada hubungan dinamis dalam lingkungan kelas interaksi yang mendirikan landasan dalam rangka untuk belajar.

Model pembelajaran Quantum merupakan model pembelajaran yang berupaya memadukan (mengintegrasikan, menyinergikan, mengelaborasikan) faktor potensi-diri manusia selaku pembelajar dengan lingkungan (fisik dan mental) sebagai konteks pembelajaran (Hamdayama, 2014). Dalam Perkembangannya model quantum teaching banyak menjadi sumber kajian tentang pengembangan pembelajaran baru yang menyenangkan. Kerangka pembelajaran Quantum Teaching dikenal sebagai TANDUR dengan kata Tumbuhkan, Alami, Namai, Demontrasikan, Ulangi dan Rayakan. Kerangka ini dapat membuat siswa menjadi tertarik dan berminat pada suatu pelajaran dan dapat juga memastikan siswa mengalami pembelajaran, berlatih, menjadikan isi pelajaran nyata bagi siswa itu sendiri, dan mencapai sukses. Dengan kerangka TANDUR dalam model pembelajaran ini dianggap mampu mencapai peningkatan motivasi belajar matematika siswa disekolah.

Walaupun model pembelajaran Quantum dapat meningkatkan motivasi belajar matematika siswa, namun dengan menerapkan model pembelajaran Quantum saja dianggap masih kurang maksimal sebelum menerapkan metode pembelajaran yang searah untuk memaksimalkan capaian indikator pemecahan masalah matematis. Metode pembelajaran yang dianggap sesuai untuk dipadukan dengan model pembelajaran Quantum adalah metode scaffolding. Pemberian model pembelajaran quantum dengan terapan metode scaffolding diharapkan searah dan sesuai agar kemampuan pemecahan masalah matematis dan motivasi belajar siswa dapat terbentuk dan meningkat dengan baik. Metode pembelajaran scaffolding merupakan pembelajaran yang didasarkan pada konsep Vygotsky tentang assisted learning. Ini adalah teknik pemberian dukungan belajar yang pada tahap awal diberikan secara lebih terstruktur, kemudian secara berjenjang menuntun siswa ke arah kemandirian belajar.

\begin{tabular}{lccr}
\multicolumn{2}{c}{ Vygotsky membatasi } & \multicolumn{2}{c}{ pembelajaran } \\
scaffolding & sebagai peranan & guru dalam \\
mendukung & perkembangan & siswa & dan
\end{tabular}
menyediakan struktur dukungan untuk mencapai tahap atau level berikutnya. Scaffolding terjadi apabila terdapat pertukaran pendapat antar peserta didik dalam memecahkan suatu masalah. Hal ini merupakan representasi dari proses interaksi sosial dikelas. Misalnya, peserta didik yang lebih mampumembimbing atau membantu peserta didik lainnya melalui pemberian petunjuk tentang cara memecahkan masalah. Jadi, tugas guru adalah menciptakan sesi brainstorming agar terjadi interaksi sosial tersebut (Silfanus, 2018). Salah satu bentuk alat dalam metode scaffolding yang dapat diimplemetasikan dalam pembelajaran adalah dialog. Menurut pandangan Vygotsky, peserta didik akan menemukan konsep-konsep yang sistematis, logis, dan rasional apabila mereka terlibat dalam pertemuan dan dialog baik dengan guru maupun peserta didik yang dianggap mampu.

Pertanyaan merupakan salah satu aspek penting dalam dialog. Pertanyaan-pertanyaan tersebut bertujuan untuk memfokuskan, mengingatkan, mengarahkan, dan sebagainya. Terdapat 5 jenis teknik scaffolding yangdapat diterapkan dalam pembelajaran matematika yaitu: offering explanation; inviting student participation; verifying and clarifying student understanding; modeling of desired behaviors dan inviting students to contribute clues. (1) Offering explanations (menyajikan penjelasan); Guru perlu menyajikan penjelasan berupa pernyataan eksplisit tentang apa yang sedang dipelajari, mengapa, kapan, dan bagaimana penggunaannya. Penjelasan tersebut disesuaikan dengan pemahaman peserta didik. (2) Inviting student 
participation (mengundang partisipasi peserta didik); Peserta didik diberi kesempatan untuk berpartisipasi dalam proses pembelajaran. Guru memberikan gambaran tentang pemikiran serta tindakan yang diperlukan untuk menyelesaikan tugas, sedangkan peserta didik diberi kesempatan untuk menggunakan apa yang telah mereka ketahui dan pahami. (3) Verifying and clarifying student understandings (Verifikasi dan klarifikasi pemahaman peserta didik); Jika respon (pemahaman peserta didik) yang muncul masuk akal, guru memverifikasi tanggapan peserta didik; Jika tidak, guru menawarkan klarifikasi. Guru menjaga setiap aktifitas peserta kemudian memotivasi mereka untuk melajutkan pekerjaannya. (4) Modeling of desired behaviors (Memperagakan perilaku tertentu); Teknik ini merupakan teknik mengajar yang menunjukkan bagaimana seseorang harus merasakan, berpikir, atau bertindak dalam situasi tertentu. (5) Inviting students to contribute clues (Mengajak peserta didik memberikan petunjuk/kunci); Menyorot konsep utama dari tugas yang diberikan. Peserta didik didorong untuk memberikan petunjuk tentang bagaimana menyelesaikan tugas yang diberikan.

Kelima teknik ini dapat digunakan secara bersamaan atau sendiri-sendiri tergantung materi yang dibahas (Bikmaz, 2010). Menerapkan metode scaffolding dalam model pembelajaran Quantum ini menjadi satu terapan yang peneliti lakukan untuk mengatasi masalah SMP Negeri 1 Torgamba yaitu meningkatkan kemampuan pemecahan masalah dan motivasi belajar matematika

\section{Metode Penelitian}

Populasi dalam penelitian ini adalah siswa SMP Negeri 1 Torgamba. Pengambilan sampel dalam penelitian ini menggunakan teknik cluster random sampling. Dengan menggunakan teknik cluster random sampling dipilih dua kelas dari enam kelas sebagai kelas sampel yaitu untuk sebagai kelas eksperimen dan kontrol dengan jumlah masing-masing kelas 30 orang.

Variabel bebas dalam penelitian ini adalah model pembelajaran Quantum terapan metode Scaffolding dan variabel terikatnya adalah kemampuan pemecahan masalah matematis dan motivasi belajar matematika. Jenis penelitian ini merupakan penelitian eksperimen semu (quasi experiment) dengan rancangan eksperimen desain faktorial $2 \times 2$. Desain penelitiannya adalah sebagai berikut:
A $\mathrm{X}_{1} \mathrm{O}_{2}$
A $\mathrm{X}_{2} \mathrm{O}_{2}$

Keterangan:

$\mathrm{A}=$ Pemilihan sampel

$\mathrm{X}_{1}=$ Model pembelajaran quantum

terapan metode scaffolding

$\mathrm{X}_{2}=$ Model pembelajaran biasa

$\mathrm{O}_{2}=$ Tes kemampuan (postes).

Penelitian ini dirancang untuk mengetahui pengaruh model pembelajaran quantum teaching dengan terapan metode scaffolding terhadap kemampuan pemecahan masalah matematis dan motivasi belajar matematika siswa. Prosedur penelitian diawali dengan studi pendahuluan untuk merumuskan identifikasi masalah, rumusan masalah, studi literatur, dan pengembangan perangkat penelitian berupa bahan ajar (materi perlakuan), model pembelajaran serta instrumen penelitian.

Instrumen penelitian pertama yang digunakan adalah soal tes yang terdiri dari Pretes dan Postes dengan masing-masing 5 soal dengan tiap soal mengandung indikator dari setiap capaian kemampuan pemecahan masalah matematis. Instrumen kedua adalah soal angket indikator motivasi belajar matematika sebanyak 25 pernyataan dengan skala likert. Sebelum instrumen penelitian diberikan pada kelas eksperimen dan kelas kontrol, terlebih dahulu diujicobakan kepada responden lain yaitu siswa kelas VII dari sekolah yang berbeda dengan sebelummya mereka telah mendapatkan materi perlakuan tersebut. Dengan demikian dapat ditentukan validitas, reliabilitas, tingkat kesukaran dan daya pembedanya.

Pelaksanaan perlakuan dengan model pembelajaran quantum pada kelas eksperimen dilakukan langsung oleh peneliti, sedangkan model pembelajaran biasa pada kelas kontrol dilakukan oleh guru matematika yang biasa mengajar dikelas tersebut. Sebelum guru tersebut mengajarkan materi ajar dengan model pembelajaran biasa, guru tersebut terlebih dahulu diberikan pengarahan tentang pelaksanaan penelitian oleh peneliti. Untuk mengamati aktifitas siswa selama pembelajaran untuk kelas eksperimen dan kontrol dilakukan observasi dengan bantuan anggota peneliti. Hasil observasi ini digunakan untuk analisis data secara kualitatif. Sedangkan analisis secara kuantitatif dilakukan terhadap data motivasi belajar dan kemampuan pemecahan masalah matematis siswa.

Teknik analisa data yang digunakan dalam penelitian ini adalah teknik statistik deskriptif dan inferensial. Teknik statistik deskriptif digunakan 
untuk mendeskripsikan data, antara lain: nilai rata-rata (mean), median, modus, standar deviasi (SD) dan kecenderungan data. Teknik statistik inferensial digunakan untuk menguji hipotesis penelitian, dimana teknik inferensial yang akan digunakan adalah teknik Analilis Varian dua jalur (disain faktorial $2 \times 2$ ) pada taraf signifikansi 5\% (Sudjana, 2000). Sebelum ANAVA dua jalur dilakukan, terlebih dahulu dilakukan uji persyaratan analisis yakni uji normalitas menggunakan uji liliefors, dan uji persyaratan homogenitas menggunakan uji Bartlett. Setelah melakukan pengujian persyaratan analisis, selanjutnya dilakukan pengujian ANAVA 2 jalur.

\section{Hasil dan Pembahasan}

Ketercapaian nilai kemampuan pemecahan masalah matematis dalam proses pembelajaran yang telah dilakukan selama penelitian diperoleh dari 2 kelas eksperimen dan kontrol pada kelas VII di SMP Negeri 1 Torgamba melalui pemberian soal pretes dan postes dalam indikator dan kisi-kisi butir soal yang sama hanya agar tidak ada perbedaan pengukuran pada kelas eksperimen dan kontrol. Pada kelas eksperimen dan kontrol, Sebelum proses belajar mengajar dimulai diberikan 5 soal pretes pada kelas masing-masing diperoleh nilai rata-rata 43,23 dan 42,95. Setelah selesai perlakuan atau pelaksanaan pembelajaran dengan menerapkan model pembelajaran quantum dengan terapan metode scaffolding maka diberikan soal postes untuk mengukur ketercapaian standar indikator kemampuan pemecahan masalah matematis siswa, dan diperoleh nilai rata-rata postest sebesar 92,34 dan 58,25 dengan Kriteria Ketuntasan Minimal (KKM) yang harus dipenuhi adalah 60,00.

Berdasarkan data hasil pretes dan postes diperoleh skor terendah $\left(X_{\min }\right)$, skor tertinggi $\left(X_{\max }\right)$, skor rata-rata $(\bar{X})$ dan standar deviasi $(s)$ untuk kelas eksperimen dan kelas kontrol seperti pada tabel 1 berikut:

Tabel 1. Data Hasil Pretest dan Postest

\begin{tabular}{ccccccccccc}
\hline Model & Skor & \multicolumn{4}{c}{ Nilai Pretest } & \multicolumn{5}{c}{ Nilai Postest } \\
\cline { 3 - 10 } Pembelajaran & Ideal & $X_{\min }$ & $X_{\text {maks }}$ & $\bar{X}$ & $s$ & $X_{\min }$ & $X_{\text {maks }}$ & $\bar{X}$ & $s$ \\
\hline Pembelajaran Quantum & & 30 & 67 & 43,23 & 9,02964 & 65 & 96 & 92,34 & 8,60897 \\
Pembelajaran Biasa & 100 & & 30 & 68 & 42,95 & 9,06540 & 40 & 75 & 58,25 & 6,12435 \\
\hline
\end{tabular}

Adapun diagram persentasi ketercapaian nilai kemampuan pemecahan masalah matematis berdasarkan hasil penelitian dapat dilihat pada gambar 1 berikut

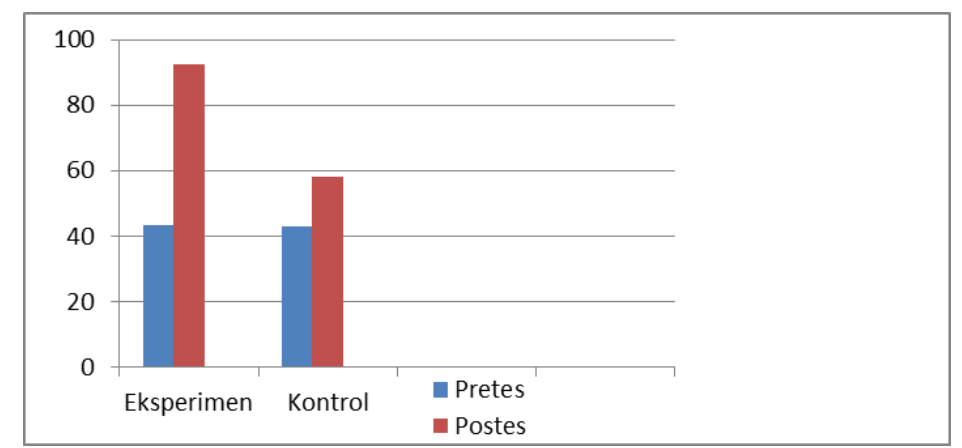

Gambar 1. Diagram Persentasi Ketercapaian Nilai Kemampuan Pemecahan Masalah

Diagram diatas merepresentasikan persentasi dari ketercapaian kemampuan pemecahan masalah matematis siswa yang diperoleh dari dua tes yaitu pretes dan postes pada dua kelas eksperimen maupun kontrol dengan sumbu y sebagai ukuran dari persentasi capaian dari kedua tes.

Adapun hasil analisis data tes lainnya ditemukan bahwa dari 30 siswa pada kelas eksperimen terdapat 12 siswa dengan hasil pretes dalam kategori kurang dengan persentase $40 \%$ dan 18 siswa kategori sangat kurang dengan persentase $60 \%$. Sedangkan hasil postes menunjukkan 5 siswa mendapatkan kategori istimewa dengan persentase $16,67 \%$ dan 25 siswa mendapatkan kategori sangat baik dengan persentase $83,33 \%$.

Instrumen penilaian kemampuan pemecahan masalah matematis mengacu pada Teori Polya yang mempunyai 4 langkah dalam menyelesaikan permasalahan yaitu (1) memahami masalah; (2) merencanakan penyelesaian; (3) menyelesaikan masalah; (4) melakukan pengecekan kembali. Adapun 
representasi perbedaan hasil skor pretes dan postes pada setiap langkah soal pemecahan masalah dapat dilihat pada gambar 2 berikut

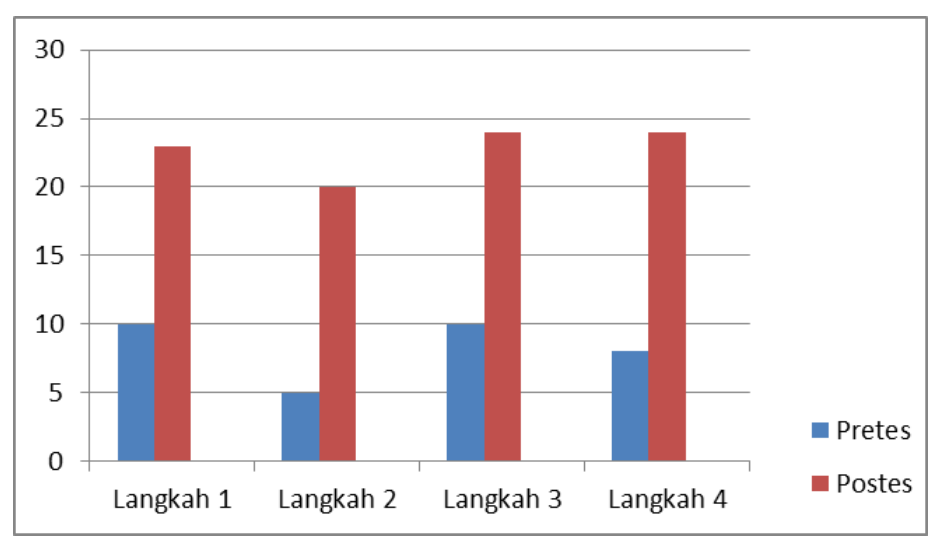

Gambar 2. Diagram Perbedaan Capaian Skor Pretes dan Postes

Berdasarkan diagram pada gambar 2 diatas dapat dilihat bahwa ketercapaian skor yang ditunjukkan pada sumbu y pada setiap langkah pemecahan masalah matematis siswa pada soal pretes dan postes menunjukkan perbedaan yang signifikan. Terlihat adanya peningkatan dari skor pretest dan posttest pada setiap langkah pemecahan masalah. Skor pretest pada langkah 1,2,3 dan 4 masing-masing adalah 10, 5, 10, dan 8 sedangkan skor posttest pada langkah 1,2,3 dan 4 masing-masing adalah 23, 20, 24, dan 24 dengan maksimal capaian skor adalah 25 pada setiap langkah. Hal ini menunjukkan bahwa ketercapaian 4 langkah dalam menyelesaikan permasalahan dalam soal tes sebagai intrumen penelitian yang diberikan pada siswa tercapai dengan baik yaitu langkah 1 memahami masalah; langkah 2 merencanakan penyelesaian; langkah 3 menyelesaikan masalah; dan langkah 4 melakukan pengecekan kembali.

Untuk mengetahui peningkatan kemampuan pemecahan masalah matematis dan motivasi belajar siswa dilihat dari analisis skor gain ternormalisasi yang ditinjau dari kategori kemampuan siswa. Data gain ternormalisasi juga menunjukkan klasifikasi peningkatan skor siswa yang dibandingkan dengan skor maksimal idealnya. Berikut disajikan rangkuman rataan $\mathrm{N}-$ Gain kemampuan pemecahan masalah matematis siswa pada kelas eksperimen dan kontrol.

Tabel 2. Rataan dan Klasifikasi N-Gain Kemampuan Pemecahan Masalah Matematis

\begin{tabular}{ccc}
\hline Kelas & Rataan N-Gain & Klasifikasi \\
\hline Eksperimen (Quantum) & 0,753 & Tinggi \\
Kontrol (Biasa) & 0,345 & Rendah \\
\hline
\end{tabular}

Berdasarkan data pada tabel 1 diatas terlihat bahwa siswa yang mendapatkan pembelajaran quantum teaching memiliki rataan skor $\mathrm{N}$-gain yang lebih besar daripada siswa yang mendapatkan pembelajaran secara konvensional (biasa). Klasifikasi skor $\mathrm{N}$-gain kelas eksperimen termasuk kategori tinggi, sementara klasifikasi skor $\mathrm{N}$-gain kelas kontrol termasuk kategori rendah. Untuk mengetahui apakah peningkatan kemampuan pemecahan masalah matematis kelas eksperimen lebih baik daripada kelas kontrol dilakukan pengujian perbedaan rataan skor $\mathrm{N}$-gain dengan uji independent t-test. Dari hasil analisis didapat p-value atau sig. (2-tailed) yaitu sig.(1tailed) $=0,00<\alpha$. Ini menunjukkan bahwa $\mathrm{H} 0$ ditolak dengan arti bahwa peningkatan kemampuan pemecahan masalah matematis siswa kelas eksperimen lebih baik daripada kelas kontrol.
Hasil pengujian statistik pada kelas eksperimen dibandingkan kelas kontrol dengan menggunakan uji $\mathrm{t}$ sebagai uji hipotesis, yaitu hasil $\mathrm{t}$ hitung $>\mathrm{t}$ tabel dimana $\mathrm{t}$ hitung $=1,43$ dan $\mathrm{t}$ tabel $=1,03$ dengan taraf signifikansi $5 \%$ sehingga $\mathrm{H}_{1}$ diterima dan $\mathrm{H}_{0}$ ditolak. Maka dapat disimpulkan bahwa terdapat pengaruh yang signifikan dari penggunaan model quantum teaching terapan metode scaffolding terhadap peningkatan kemampuan pemecahan masalah Imatematis siswa daripada dengan model pembelajaran biasa.

Adapun data hasil penelitian dari motivasi belajar matematika siswa diperoleh dari pemberian instrumen angket yang tersusun dari 25 pernyataan terdiri dari 20 pernyataan positif dan 5 pernyataan negatif. Skor yang digunakan mewakili enam aspek motivasi belajar yaitu adanya hasrat dan keinginan berhasil, adanya 
dorongan dan kebutuhan dalam belajar, adanya harapan dan cita-cita masa depan, adanya penghargaan dalam belajar, adanya kegiatan yang menarik dalam belajar dan adanya lingkungan belajar yang kondusif, dengan skor maksimum setiap butir adalah 4. Angket motivasi belajar siswa ini diberikan pada kelas eksperimen dan kelas kontrol pada awal pembelajaran dan akhir pembelajaran. Skor dari angket motivasi belajar tersebut sebelumnya dalam bentuk data ordinal kemudian diubah kedalam data interval dengan methode successive interval. Hasil penskoran dan transformasi data tersebut dapat dilihat dalam rangkuman deskripsi skor dalam tabel 2 dibawah ini.

Tabel 3. Rataan Skor Angket Motivasi Belajar Siswa

\begin{tabular}{c|c|c|c}
\hline Kelas & $\begin{array}{c}\text { Rataan Skor Sebelum } \\
\text { Pembelajaran }\end{array}$ & $\begin{array}{c}\text { Rataan Skor Sesudah } \\
\text { Pembelajaran }\end{array}$ & N-Gain \\
\hline Eksperimen & 52,34 & 82,87 & 0,72 \\
Kontrol & 53,21 & 64,53 & 0,43 \\
\hline
\end{tabular}

Analisis skor N-gain motivasi siswa menggunakan data gain ternormalisasi dengan dilakukan pengujian perbedaan rataan skor $\mathrm{N}$-gain dengan uji independent t-test. Dari hasil uji tersebut didapat nilai p-value atau Sig.(1-tailed) yaitu Sig.(1-tailed) $=0,0121<\alpha$. Hal ini menunjukkan bahwa Ho ditolak artinya peningkatan kemampuan motivasi belajar siswa kelas eksperimen lebih baik daripada kelas kontrol.

Adapun hasil analisis dari pengujian statistik menggunakan Uji t pada taraf signifikansi $\alpha=0,05$ diperoleh $t_{\text {hitung }}$ sebesar 5,83 dengan nilai signifikansi 0,000 sedangkan $\mathrm{t}_{\text {tabel }}$ sebesar 4,42. Karena $\mathrm{t}_{\text {hitung }}>\mathrm{t}_{\text {tabel }}(5,83>4,42)$ dan signifikansi $<0,05(0,000<0,05)$, maka $\mathrm{H}_{0}$ ditolak. Oleh karena itu disimpulkan bahwa ada pengaruh yang signifikan dari penggunaan model quantum teaching terapan metode scaffolding terhadap peningkatan motivasi belajar matematika siswa daripada dengan model pembelajaran biasa

\section{Kesimpulan}

Peningkatan kemampuan pemecahan masalah matematis dan motivasi belajar siswa melalui model quantum teaching terapan metode scaffolding lebih baik daripada melalui model pembelajaran biasa. Penerapan model quantum teaching terapan metode scaffolding pada pembelajaran matematika dikelas sangat berpengaruh signifikan terhadap peningkatan motivasi belajar, dengan meningkatnya motivasi belajar siswa secara signifikan juga berpengaruh terhadap kemampuan matematis siswa khususnya kemampuan pemecahan masalah matematis.

Model pembelajaran ini memberikan dampak baik terhadap capaian dalam pembelajaran matematika. Model dan metode pembelajaran ini diharapkan dapat digunakan secara berkelanjutan dalam upaya meningkatkan kemampuan matematis lainnya. Peneliti akan mengoptimalkan hasil penelitian ini untuk dapat digunakan oleh para guru ataupun peneliti lainnya dalam hal pembelajaran matematika.

\section{Ucapan Terima Kasih}

$$
\text { Ucapan terimakasih kepada }
$$

Kemendikbudristek Direktorat Jenderal Pendidikan Tinggi, Riset dan Teknologi karena telah memberikan kontribusi dan dukungan yang besar untuk program penelitian dalam meningkatkan mutu pendidikan di Indonesia

\section{Daftar Pustaka}

Bikmaz, F.H, et al. (2010). Scaffolding Strategies Applied by Student Teachers to Teach Mathematics. The International Journal of Research in Teacher Education. Vol. 1(special Issue), pp. 25-36

Dimyati, Mudjiono. (2013). Belajar Dan Pembelajaran. Jakarta: Rineka Cipta.

Hasibuan, LR. (2019). Pengaruh Model Pembelajaran Kooperatif Tipe Course Review Horay (CRH) Terhadap Hasil Belajar Matematika Siswa pada Materi Persamaan Linear Satu Variabel di Kelas VII SMP Negeri Rantau Selatan. Jurnal Pembelajaran dan Matematika Sigma (JPMS). vol.5 no. 1 mei (2019)

Hasanah, Ulfatun. 2020. Hubungan antara Metode Belajar dan Motivasi Belajar dengan Prestasi. Al-Muaddib, vol.II no.1 April (2020)

Hamdayama, J. (2014). Model dan Metode Pembelajaran Kreatif Berkarakter. Bogor: Ghalia Indonesia.

Hendriana, H., Soemarmo, U. (2016). Penilaian Pembelajaran Matematika. Bandung: PT. Refika Aditama

Hendriana, H., Soemarno, U. (2016). Penilaian Pembelajaran matematika. Bandung: Refika Aditama 
Made, Wena. (2013). Strategi Pembelajaran Inovatif Kontemporer: Suatu Tinjauan Konseptual Operasional. Jakarta: Bumi Aksara.

Prabawanto, Sufyani.(2013). Meningkatkan kemampuan pemecahan masalah, komunikasi, dan self-effacy matematis mahasiswa melalui pembelajaran dengan pendekatan metacogniteve scaffolding. Bandung: UPI

Rianto, V. M., Yusmin, E., \& Nursangaji, A. (2017). Kemampuan Pemecahan Masalah Siswa Berdasarkan Teori John Dewey pada Materi Trigonometri. Jurnal Pendidikan Matematika FKIP Untan, 6(7)

Sumarmo, U. (2012). Pendidikan Karakter serta Pengembangan Berfikir dan Disposisi Matematika dalam Pembelajaran Matematika. Makalah disajikan dalam Seminar Pendidikan Matematika. NTT, 25 Februari 2012
Silfanus, Jelatu. (2018). Scaffolding Dalam Pembelajaran Matematika: Optimalisasi Peran Guru Sebagai Fasilitator. Prosiding: Seminar Nasional Pendidikan Matematikai 2018 (21-29). Program Studi Pendidikan Matematika Stkip Santu Paulus

Sudjana, Nana. (2000). Dasar-Dasar Proses Belajar Mengajar. Bandung: PT. Sinar. Baru Algensindo

Tomo, Yusmin, E., \& Riyanti, S. (2016). Kemampuan Pemecahan Masalah Siswa pada Materi Bangun Datar di SMP. 5(5)(1), 1-11.

Uno, Hamzah, B. (2010). Teori Motivasi dan Pengukurannya, Jakarta: Bumi Aksara

Widayanti, D. (2011). Motivasi Belajar Siswa Pada Pembelajaran Matematika. Prosiding Seminar Nasional Matematika. Surakarta. 